\title{
PENGARUH PENDIDIKAN AKHLAK TERHADAP PERILAKU SANTRI DI PONDOK PESANTREN AS-SHIDDIQIYAH
}

\author{
Ummu Kulsum \\ Fakultas Ekonomi dan Bisnis Islam IAIN Madura \\ Email: mamiex.cilmut@gmail.com
}

\begin{abstract}
This study entitled about education involves many things that must be pondered. Because education includes all human behavior that is carried out for the sake of obtaining continuity, defense and improvement of life. In the language of religion, in order to gain the pleasure of Allah. So that the whole behavior forms the integrity of a virtuous human being (having good character). The urgency of moral education for students or society because it is something that becomes behavior (Sulukiyah) in everyday life and becomes a mirror of one's life in society and the state. To achieve these objectives the researchers used a quantitative approach. Data collection techniques using interviews, observation, interviews and questionnaires. The data analysis technique uses data interpretation analysis using the Simple Regression formula. The results of this study indicate that there are three models of moral education. The First is a rational moral model. The Second is a religious moral model. The Third is an eclectic moral model. Asshiddiqiyah Islamic boarding school in its moral education uses an eclectic moral education model. The results of this study indicate that moral education carried out in Islamic boarding schools can have a very significant influence on the behavior of students, this can be seen from the results of the questionnaire calculation, namely the tcount is greater than 19,041 than t. the table is good at a significant level of 0.05: 3.99 and at a level of 0.01: 7.04, so the magnitude of rxy is 0.219, which is $=0.219$. which implies that $21.9 \%$ of the variation in student behavior can be explained by moral education.
\end{abstract}

Keywords: Moral Education, Behavior, Boarding School.

\begin{abstract}
Abstrak
Penelitian terkait dengan pendidikan akhlak terhadap anak didik atau masyarakat karena ia merupakan sesuatu yang menjadi tingkah laku (Sulukiyah) dalam kehidupan sehari-hari dan menjadi cermin hidup seseorang dalam bermasyarakat maupun bernegara. Akhlak tidak dapat dipisahkan dalam kehidupan manusia yang pada hakikatnya mempunyai potensi sebagai moral being. Metode penelitian ini menggunakan pendekatan kuantitatif. Teknik pengumpulan datanya menggunakan interview, observasi, wawancara dan penyebaran angket. Adapun teknik analisis datanya menggunakan analisis interpretasi data dengan menggunakan rumus Regresi Sederhana. Hasil dari penelitian ini menunjukkan bahwa model pendidikan akhlak ada tiga model. Pertama adalah model akhlak rasional. Kedua, model akhlak religious. ketiga model akhlak elektik. Pondok pesantren Asshiddiqiyah dalam pendidikan akhlaknya menggunakan model pendidikan akhlak elektik. Hasil penelitian ini menunjukkan bahwa pendidikan akhlak yang dilakukan di pondok pesantren dapat memberikan pengaruh yang sangat signifikan terhadap perilaku santri, hal ini dapat di lihat dari hasil perhitungan angket yaitu di dapat $t$ hitung lebih besar 19.041 dari pada t tabel baik pada taraf signifikan $0,05: 3.99$ dan pada taraf $0.01: 7.04$, sehingga besarnya rxy adalah 0,219 , yaitu $r^{2} x y=0,219$. yang mengandung makna bahwa $21.9 \%$ variasi perilaku santri dapat dijelaskan oleh pendidikan akhlak.
\end{abstract}

Kata Kunci: Pendidikan Akhlak, Perilaku, Pesantren. 


\section{PENDAHULUAN}

Membicarakan pendidikan melibatkan banyak hal yang harus direnungkan. Sebab pendidikan meliputi keseluruhan tingkah laku manusia yang dilakukan demi memperolah kesinambungan, pertahanan dan peningkatan hidup. Dalam bahasa agama, demi memperoleh ridha Allah. Sehingga keseluruhan tingkah laku tersebut membentuk keutuhan manusia berbudi luhur (ber-akhlaq karimah). Seperti dikutip M.Arifin, dari John Dewey berpendapat bahwa pendidikan adalah sebagai suatu proses pembentukan kemampuan dasar yang fundamental, baik menyangkut daya pikir (intelektual) maupun daya perasaan (emosional) menuju kearah tabiat manuisa dan manusia biasa. ${ }^{1}$

Ahklak merupakan tiang berdirinya umat, sebagaimana shalat sebagai tiang agama Islam. Dengan kata lain apabila rusak akhlak suatu umat maka rusaklah bangsanya.

Penyair besar Syauqi pernah menulis:

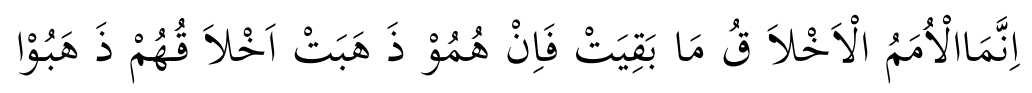

Sesungguhnya kejayaan suatu umat (bangsa) terletak pada akhlaknya selagi mereka berakhlak/berbudi perangai utama, jika pada mereka telah hilang akhlaknya, maka jatuhlah umat (bangsa) ini. ${ }^{2}$

Akhlak dapat dijadikan tolak ukur tinggi rendahnya suatu bangsa. Seseorang akan dinilai bukan karena jumlah materinya yang melimpah, ketampanan wajahnya dan bukan pula karena jabatannya yang tinggi. Allah SWT akan menilai hamba-Nya berdasarkan tingkat ketakwaan dan amal (akhlak baik) yang dilakukannya. Seseorang yang memiliki akhlak mulia akan dihormati masyarakat akibatnya setiap orang di sekitarnya merasa tentram dengan keberadaannya dan orang tersebut menjadi mulia di lingkungannya.

Pendidikan akhlak merupakan permasalahan utama yang selalu menjadi tantangan bagi manusia sepanjang sejarahnya. Sejarah kehidupan bangsa- bangsa baik yang diabadikan dalam Al-Qur'an seperti kaum 'Ad, Tsamud, Luth, Madyan, dan Saba'3 maupun yang didapat dalam buku-buku sejarah menunjukkan bahwa suatu bangsa akan kokoh dan jaya apabila akhlaknya baik, dan sebaliknya suatu bangsa akan runtuh apabila

${ }^{1}$ Muzayyin Arifin, Filsafat Pendidikan Islam Edisi Revisi (Bumi Aksara, 2017).

${ }^{2}$ Umar Bin Ahmad Baraja, “Akhlak lil banin,” Juz II. Surabaya: Ahmad Nabhan, tth, 1987.

${ }^{3}$ Kaum 'Ad adalah kaum Nabi Hud, mereka membangkan atas seruan Nabi Hud untuk menyembah Allah dan mengatakan Nabi Hud sebagai orang yang kurang akal. Baca surat Hud (11) ayat 50-60, juga surat $A l-A$ 'raf ayat 65-72. Kaum Tsamud adalah kaum Nabi Shaleh yang menolak risalah Nabi Shaleh, akhirnya mereka mendapat siksaaan dari Allah, baca surat $A l$ '-A'raf ayat 73-79. Kaum Luth merupakan pengikut Nabi Luth dikenal sebagai golongan manusia pertama kali melakukan perbuatan fahisyahi,yaitu homoseksual akhirnya mereka disikasa dengan hujan batu, baca surat $A l-A$ 'raf ayat 80 . Kaum Madyan adalah kaum Nabi Syau'aib, mereka tidak mau menyembah Allah, bahkan mereka mencoba mengusir Nabi Syu'aib dari kampungnya, baca surat $A l-A$ 'raf ayat 85, surat At Taubah ayat 70. Kaum Saba' adalah sebuah kerajaan yang dipimpin oleh wanita (Ratu Balqis), rakyatnya menyembah matahari, dan akhirnya mereka masuk Islam setelah Nabi Sualaiman menyeru mereka masuk Islam.

51 | Qiro'ah| Vol. 11 No. 22021 
akhlaknya rapuh. ${ }^{4}$ Nabi Muhammad Saw yang diyakini oleh umat Islam sebagai pembawa risalah Tuhan yang terakhir, sudah sejak awal abad ke-7 Masehi secara tegas telah menyatakan bahwa tugas utamanya adalah sebagai pnyempurna akhlak manusia. Dalam Al-Qur'an terdapat pula pernyataan bahwa, ia adalah seorang yang berakhlak agung, karena itu ia patut dijadikan contoh.

Kebesaran Nabi Muhammad ternyata memperoleh pengakuan sebagai tokoh urutan pertama yang paling berpengaruh dalam sejarah non-muslim ${ }^{5}$, Kebesaran Nabi Muhammad tentunya disebabkan oleh ketinggian akhlaknya, karena itu, tujuan pendidikan akhlak Islam harus diarahkan pada terciptanya manusia yang berakhlak agung seperti Nabi Muhammad Saw. ${ }^{6}$

Urgennya pendidikan akhlak ini terhadap anak didik atau masyarakat karena ia merupakan sesuatu yang menjadi tingkah laku (Sulukiyah) dalam kehidupan sehari-hari dan menjadi cermin hidup seseorang dalam bermasyarakat maupun bernegara. Akhlak tidak dapat dipisahkan dalam kehidupan manusia yang pada hakikatnya mempunyai potensi sebagai moral being.

Ibnu Qayyim mengemukakan bahwa pendidikan akhlak adalah melatih anak untuk berkhlak mulia dan memiliki kebiasaan yang terpuji, sehingga akhlak itu menjadi karakter dan sifat yang tertanam di dalam pribadi anak, serta mampu meraih kebahagiaan hidup, terbebas dari jeratan akhlak yang buruk (al-Akhlak al-Madmumah). ${ }^{7}$ Menurut AlGhazali pendidikan akhlak adalah terbentuknya sikap batin yang mendorong terciptanya keutamaan jiwa yang disebut al-Ghazali dengan kebahagiaan hakiki (al-sa'adat alhaqiqiyah). ${ }^{8}$

Pendidikan akhlak sebagaimana dirumuskan oleh Ibn Miskawaih, merupakan upaya ke arah terwujudnya sikap batin yang mampu mendorong secara spontan lahirnya perbuatan-perbuatan yang bernilai baik dari seseorang. ${ }^{9}$ Dalam pendidikan akhlak ini, kriteria benar dan salah untuk menilai perbuatan yang muncul merujuk kepada Al-Qur' an dan Sunah sebagai sumber tertinggi dalam ajaran Islam. Dengan demikian maka pendidikan akhlak dapat dikatakan sebagai pendidikan moral dalam diskursus pendidikan Islam. Telaah lebih dalam terhadap konsep akhlak yang telah dirumuskan oleh para tokoh pendidikan Islam masa lalu seperti Ibnu Miskawaih.

Tujuan pendidikan akhlak adalah terbentuknya karakter positif dalam perilaku anak didik. Namun demikian dalam implementasinya, pendidikan akhlak yang dimaksud

\footnotetext{
${ }^{4}$ Al-Siba'i Bayuni, Al-Adab wa al-Nushush, (Kairo : Dar al-Nahdhah al-Mishr, 1975),h.225

${ }^{5}$ Michael H. Hart, The 100: A ranking of the most influential persons in history (Citadel press, 1978).

${ }^{6}$ Abdul-Rahman Salih Abdullah, "Educational theory: a Qur' ānic outlook," Annexe Thesis Digitisation Project 2017 Block 15, 1981.

${ }^{7}$ Ibnu Qayyim al-Jauziyah, Tuhfat al-Maud̂̂d bi Ahkâm al-Maulûd, (Beirut : Maktabah al-Mutanabi, tt), h. 240

${ }^{8}$ Al-Ghazali, Mizan al- 'Amal, Sualiman Dunya (ed), (Kairo : Dar al-Ma'arif, 1964), h.303

${ }^{9}$ Robiatul Adawiyah, "Konsep Pendidikan Akhlak Ibnu Miskawaih” (B.S. thesis, Jakarta: FITK UIN Syarif Hidayatullah Jakarta, 2017).
} 
Qiro'ah| Jurnal Pendidikan Agama Islam

Vol. 11 No. 2 2021| https:/ejurnal.iiq.ac.id/index.php/qiroah

P-ISSN: 2085-0115 E-ISSN: 2656-3819

DOI: https://doi.org/10.33511/qiroah.v21n1.31-55

memang masih tetap cenderung pada pengajaran benar dan salah seperti halnya pendidikan moral. Menjamurnya lembaga-lembaga pendidikan Islam di Indonesia dengan pendidikan akhlak sebagai trade mark di satu sisi, dan menjamurnya tingkat kenakalan perilaku amoral remaja di sisi lain menjadi bukti kuat bahwa pendidikan akhlak dalam lembaga-lembaga pendidikan Islam sepertinya masih belum optimal.

Al-Abrasyi merumuskan lima tujuan pendidikan Islam di antaranya, untuk pertama, mengadakan pembentukan akhlak yang mulia, karena akhlak yang sempurna adalah tujuan pendidikan Islam yang sebenarnya. Kedua, persiapan untuk kehidupan dunia dan kehidupan akhirat. Ketiga, persiapan untuk mencari rizki dan pemeliharaan segi manfaat atau tujuan vokasional dan professional. Keempat, untuk menumbuhkan semangat ilmiah pada pelajar dan memuaskan keinginan tahu (curiosity) dan memungkinkan ia untuk mengkaji ilmu demi ilmu itu sendiri. Kelima, untuk menyiapkan pelajar dari segi professional, teknikal dan pertukangan supaya dapat menguasai profesi tertentu, dan keterampilan pekerjaan tertentu agar ia dapat mencari rizki dalam hidup disamping memelihata segi kerohanian dan keagamaaan. ${ }^{10}$

Konferensi internasional pertama di Mekkah 8 April 1977 yang merumuskan tujuan pendidikan Islam bahwa pendidikan harus diarahkan untuk mencapai pertumbuhan keseimbangan kepribadian manusia menyeluruh, melalui latihan jiwa, intelek, jiwa rasional, perasaan, dan penghayatan lahir. Karena itu pendidikan harus menyiapkan pertumbuhan manusia dalam segi: spiritual, intelektual, imajinatif, jasmani, ilmiah, linguistik, baik individu maupun kolektif, dan semua itu didasari oleh motivasi mencapai kebaikan dan perfeksi. Tujuan akhir pendidikan muslim itu terletak pada (aktivitas) merealisasikan pengabdian kemanusiaan seluruhnya. ${ }^{11}$

Mengingat pentingnya pendidikan akhlak bagi terciptanya kondisi lingkungan yang harmonis, diperlukan upaya serius untuk menanamkan nilai-nilai tersebut secara intensif, pesantren merupakan salah satu lembaga pendidikan yang menanankan nilai-nilai akhlak agar tercipta penerus bangsa yang berbudi luhur. Pendidikan akhlak berfungsi sebagai panduan bagi manusia agar mampu memilih dan menentukan suatu perbuatan dan selanjutnya menetapkan mana yang baik dan mana yang buruk.

Perilaku manusia adalah semua kegiatan atau aktifitas manusia, baik yang dapat diamati langsung maupun yang tidak dapat diamati pihak luar. Sedangkan menurut Hilgard dan Bower mengemukakan bahwa belajar berhubungan dengan perubahan tingkah laku seseorang terhadap suatu situasi tertentu yang disebabkan oleh pengalamanya yang berulang-ulang dalam situasi itu, dimana perubahan tingkah laku itu tidak dapat dijelaskan atau dasar kecenderungan respon pembawaan.

Menurut Chaplin, prilaku atau tingkah laku merupakan sembarang respon yang

\footnotetext{
${ }^{10}$ Aiyah al Abrasyi, “Al-Tarbiyah al-Islamiyah wa Falsifatuh,” Cet. III, Mesir: Isa al-Baby alHalaby, t. th, t.t.

${ }^{11}$ Muhammad Iqbal, "First world conference on Muslim education and its possible implications for British Muslims," Learning for Living 17, no. 3 (1978): 123-25.
}

53 | Qiro'ah| Vol. 11 No. 22021 
mungkin berupa reaksi, tanggapan, jawaban atau balasan yang dilakukan oleh organism, secara khusus prilaku berarti suatu perbuatan atau aktivitas. ${ }^{12}$ Pengertian prilaku juga berarti meliputi kegiatan atau aktifitas yang melibatkan aspek motorik, kognitif, dan emosional. $^{13}$

Dari penjelasan ahli di atas, dapat diambil kesimpulan bahwa belajar pada hakekatnya adalah proses perubahan perilaku siswa dalam bakat pengalaman dan pelatihan. Artinya tujuan kegiatan belajar mengajar ialah perubahan tingkah laku, baik yang menyangkut pengetahuan, keterampilan, sikap, bahkan meliputi segenap aspek pribadi.

Pesantren adalah lembaga pendidikan tradisional Islam tertua ${ }^{14}$ yang berusaha menanamkan pemahaman, penghayatan, dan pengalaman ajaran agama Islam (tafaqquh fi al-din) dengan menekankan pentingnya moral agama Islam sebagai pedoman hidup bermasyarakat sehari-hari ${ }^{15}$. Penyelenggaraan lembaga pendidikan di pesantren berbentuk asrama, yang merupakan komunitas tersendiri di bawah pimpina kyai dan dibantu beberapa orang ustdz yang hidup bersama di tengah-tengah para santri dengan masjid sebagi pusat kegiatan peribadatan keagamaan. Gedung-gedung sekolah atau ruang-ruang belajar adalah pusat kegiatan belajar mengajar semantara asrama adalah tempat itnggal para santri. ${ }^{16}$

Arus modernisasi telah menyebabkan tantangan yang dihadapi pesantren menjadi semakin besar, kompleks dan mendesak. ${ }^{17}$ Pergeseran-pergeseran nilai di pesantren, baik nilai-nilai yang memiliki titik singgung pada pola pengajaran terutama dalam bidang akhlak. Dalam proses pembelajaran dan interaksi sosial, ada tradisi yang dijunjung tinggi oleh komunitas pesantren yaitu budaya hormat (ta'dhim) dan patuh (sami'na wa atha'na) kepada kyai, para guru dan seniornya. Djohan Effendi dalam Hasbi Indra berpendapat bahwa pesantren adalah sebuah Kampung Peradaban ${ }^{18}$ dan Abdurrahaman Wahid

\footnotetext{
${ }^{12}$ Haji Ramayulis, "Psikologi agama," 2019.

${ }^{13}$ Ramayulis.

${ }^{14}$ Ali Maulida, "Dinamika dan Peran Pondok Pesantren dalam Pendidikan Islam Sejak Era Kolonialisme Hingga Masa Kini,” Edukasi Islami: Jurnal Pendidikan Islam 5, no. 09 (2017): 16.

${ }^{15}$ Maulida.

${ }^{16}$ Mastuhu, Dinamika Sistem Pendidikan Pesantren, (Jakarta : INIS, 1994), h. 6.

${ }^{17}$ Dalam menanggapi modernisasi umat Islam secara umum terbagi atas tiga bagian : bagian pertama merespon secara berbalikan, yaitu sikap anti modernism dan bahkan "anti Barat". Sedangkan yang keduan terpengaruh olah pola modernisasi dan beranggapan bahwa dalam konteks beragama perlu adanya pemisahan antara agama dan masalah-masalah politik ataupun permasalahn keduniawian lalinnya. Dan yang ketiga lebih bersikap kritis, namun tidak secar otomatis anti modernisasi atau anti Barat. Dalam kaitannya dengan pondok pesantren, ada yang menyikapinya dengan sikap pertama yang "anti Barat" ini biasanya didominasi oleh pesantren-pesantren salafiyah yang masih tetap ingin mempertahankan kesalafiyahannya. Sedangkan yang lain bersikap seperti kelompok ketiga yang ingin berusaha mengambil apa yang baik dari modernisasi meskipun tidak seluruhnya. Qodri Azizy, Melawan Globalisasi, Reinterpretasi Ajaran Islam Persipan SDM dan Terciptanya Masyarakat Madani, (Yogyakarta : Pustaka Pelajar, 2003), h. 28.

${ }^{18}$ Lihat Djohan Effendi, Pesantren dan Kampung Peradaban, Sebuah Pengantar, dalam Hasbi Indra, Pesantren dan Transformasi Sosial, Studi atas Pemikiran KH. Abdullah Syafi 'ie Bidang Pendidikan Islam,
} 
Qiro'ah| Jurnal Pendidikan Agama Islam

Vol. 11 No. 2 2021| https:/ejurnal.iiq.ac.id/index.php/qiroah

P-ISSN: 2085-0115 E-ISSN: 2656-3819

DOI: https://doi.org/10.33511/qiroah.v21n1.31-55

memandang pesantren sebagai sebuah Subkultur Masyarakat ${ }^{19}$ yang dengan segala kesederhanaan dan kekurangannya ternyata menyimpan potensi besar yang telah terbukti dapat melakukan transformasi peradaban Islam dan menawarkan beragam kiat, strategi dan soslusi dalam mewujudkan masyarakat madani. Pesantren inklusif, menghargai pluralisme dan menjunjung tinggi perbedaan pandapat, adalah kawah candradimuka bagi para kyai membina para santrinya menjadi orang yang bukan saja berilmu, tetapi juga berakhlak mulia, terbuka, mandiri, toleran, dan memiliki sifat-sifat humanis dan demokratis yang kelak pasca belajar di pesantren mereka dapat menjadi agent of change dan transformator social di tengah masyarakat. ${ }^{20}$

Pesantren sebagai lembaga pendidikan Islam telah banyak mencetak kader pendidik masyarakat, pengemban misi agama dan penetralisir budaya-budaya yang merusak akhlak, hal ini dibuktikan dengan adanya ketahanan keislaman masyarakat Indonesia selama 350 tahun dijajah dan diganggu akidahnya oleh Belanda, selama penjajahan yang begitu panjang pesantren sebagai basis pendidikan Islam dan akhlak telah mampu menunjukkan peranannya dalam sejarah, bahkan diakui oleh Syafi'ie Ma'arif, bahwa pesantren mempunyai andil dalam mempertahankan status qou keislaman akibat tantangan modernitas dari penetrasi budaya kolonial. ${ }^{21}$

Dalam upaya menghadapi tantangan kerusakan akhlak bangsa, pondok pesantren merupakan salah satu lembaga yang bertujuan membentuk akhlak karimah terhadap para santri atau pelajar. Salah satunya adalah pondok pesantren Asshiddiqiyah Jakarta, yang didirikan oleh KH. Noer Muhammad Iskandar pada tanngal 1 Juli 1985. Pada awalnya pesantren Assdiddiqiyah hanya bermodalkan mushalla kecil di atas tanah wakaf dan hanya memiliki dua orang santri saja, dari tahun ke tahun santrinya terus meningkat.

Melihat dinamika perkembangan santri yang semakin meningkat, maka KH. Noer Muahammad Iskandar mendirikan sekolah formal sistem klasikal yaitu Madrasah Ribathiyah (halaqah salafiyah). Kemudian awal tahun 1986 didirikan sekolah formal Madrasah Tsanawiyah dan Aliyah "Mamba'ul Ulum" pondok pesantren Asshiddiqiyah Jakarta. $^{22}$

(Jakarta : Paramadani, 2003), h.xvii.

${ }^{19}$ Abdurraman Wahid, Pesantren Sebagai Subkultur, dalam Amin Haidari, Panorama Pesantren dalam Cakrawala Modern, (Jakarta : Diva Pustaka, 2004), cet. Ke-1, h.1. tiga elemen dasar yang mampu membentuk pondok pesantren sebagai subkultur yaitu pola kepemimpinan pondok pesantren yang mandiri, kitab-kitab rujukan umum yang selalu digunakan dari berbagai abad dan sistem nilai (value) yang digunakan adalah bagian dari masyarakt luas. Dalam perkembangan pesantren kekinian konsep "subkultur" ditolak karena hanya mampu menjelaskan dunia pesanten yang belum bersentuhan dengan dunia luar. Yang lebih tepat adalah "institusi kultural" yang mengandung konotasi lebih longgar dari pada subkultural yang bersifat feniminal. Lihat Hadi Mulyo, Dua Pesantren, Dua Wajah Budaya, dalam M Dawam Harardjo

${ }^{20}$ Hasbi Indra, Pesantren dan Transformasi Sosial, Studi atas Pemikiran KH. Abdullah Syafi'ie Bidang Pendidikan Islam, (Jakarta : Paramadani, 2003), h. 15.

${ }^{21}$ Samsul Arifin, Spiritualitas Islam dan Peradaban Masa Depan, (Yogyakarta : Sippress, 1996), h. 51

${ }^{22}$ Majalah, 10 Tahun Asshiddiqiyah : Renungan Dari Catatan Sebuah Perjalanan, (Jakarta : PT. 55 | Qiro’ah| Vol. 11 No. 22021 
Berawal dari Idealisme yang tinggi, KH. Noer Muhammad Iskandar memiliki obsesi untuk mendidik santrinya menjadi orang-orang yang jujur, berakhlakul karimah, berwawasan luas, dan memiliki komitmen tinggi dalam memperjuangkan 'izzatul Islam wal Muslimin, sebagaimana tercermin pada figure sahabat Rasulullah SAW yakni Abu Bakar Asshiddiq. Beliau adalah sahabat Nabi yang semasa hidupnya tidak pernah lepas dari pengabdian dan perjuangan untuk Islam, dan telah menjadi isnpirator bagi KH. Noer Muhammad Iskandar untuk mewujudkan pondok pesantren Asshiddiqiyah.

Sesuai dengan Akta Notaris No. 18, Ghufron Kamal SH, tahun 1985, bahwa tujuan didirikannya Yayasan Pondok Pesantren Asshiddiqiyah Jakarta adalah sebagai berikut:

1. Membentuk masyarakat yang bertakwa kepada Allah, cinta agama, bangsa dan Negara.

2. Meningkatkan perkembangan pendidikan dan perkembangan Islam dalam arti seluas-luasnya.

3. Melaksanakan amal social, mengurus/memlihara anak yatim piatu dan fakir miskin.

\section{METODE PENELITIAN}

Penelitian menggunakan jenis penelitian kuantitatif. Teknik pengumpulan datanya menggunakan interview, observasi, wawancara dan penyebaran angket. Adapun teknik analisis datanya menggunakan analisis interpretasi data dengan menggunakan rumus Regresi Sederhana.

Setelah diperoleh data dari hasil angket yang diberikan kepada responden berdasarkan sampel kemudian data tersebut diolah dalam bentuk tabel deskripsi prosentase dengan menggunakan rumus distribusi frekuensi sebagai berikut :

$\mathrm{P}=\frac{F}{N} \times 100 \%$

Keterangan :

$\mathrm{P}=$ Angka prosentase

$\mathrm{F}=$ Frekuensi

$\mathrm{N}=$ Jumlah Responden.

Dari data angket kedua variabel di atas, maka untuk mengetahui apakah ada pengaruh pendidikan akhlak (variabel X) terhadap prilaku santri (variabel Y), maka penulis menggunakan rumus Analisis Regresi Sederhana yaitu $\mathbf{Y}=\mathbf{a}+\boldsymbol{\beta} \mathbf{X}+\boldsymbol{\varepsilon}$ dan $\hat{\mathbf{Y}}=\mathbf{a}$ $+\mathbf{b X}$. Kemudian memasukkan data yang diperoleh dari perhitungan angket variabel $\mathrm{X}$ dan variabel Y ke dalam tabel, sebagaimana tabel berikut ini : 
Qiro'ah| Jurnal Pendidikan Agama Islam

Vol. 11 No. 2 2021| https://ejurnal.iiq.ac.id/index.php/qiroah

P-ISSN: 2085-0115 E-ISSN: 2656-3819

DOI: https://doi.org/10.33511/qiroah.v21n1.31-55

\section{Persiapan Regresi Sederhana}

Korelasi antara Variabel $X$ dengan Variabel $Y$

\begin{tabular}{|c|c|c|c|c|c|}
\hline No & $\mathrm{X}$ & $\mathrm{Y}$ & $\mathrm{X}^{2}$ & $\mathrm{Y}^{2}$ & $\mathrm{XY}$ \\
\hline 1 & 129 & 131 & 16641 & 17161 & 16899 \\
\hline 2 & 152 & 143 & 23104 & 20449 & 21736 \\
\hline 3 & 129 & 144 & 16641 & 20736 & 18576 \\
\hline 4 & 132 & 126 & 17424 & 15876 & 16632 \\
\hline 5 & 144 & 154 & 20736 & 23716 & 22176 \\
\hline 6 & 136 & 120 & 18496 & 14400 & 16320 \\
\hline 7 & 134 & 125 & 17956 & 15625 & 16750 \\
\hline 8 & 124 & 133 & 15376 & 17689 & 16492 \\
\hline 9 & 126 & 141 & 15876 & 19881 & 17766 \\
\hline 10 & 125 & 118 & 15625 & 13924 & 14750 \\
\hline 11 & 147 & 141 & 21609 & 19881 & 20727 \\
\hline 12 & 119 & 135 & 14161 & 18225 & 16065 \\
\hline 13 & 126 & 113 & 15876 & 12769 & 14238 \\
\hline 14 & 134 & 135 & 17956 & 18225 & 18090 \\
\hline 15 & 122 & 123 & 14884 & 15129 & 15006 \\
\hline 16 & 122 & 147 & 14884 & 21609 & 17934 \\
\hline 17 & 137 & 132 & 18769 & 17424 & 18084 \\
\hline 18 & 113 & 128 & 12769 & 16384 & 14464 \\
\hline 19 & 131 & 122 & 17161 & 14884 & 15982 \\
\hline 20 & 107 & 114 & 11449 & 12996 & 12198 \\
\hline 21 & 125 & 128 & 15625 & 16384 & 16000 \\
\hline 22 & 116 & 111 & 13456 & 12321 & 12876 \\
\hline 23 & 116 & 111 & 13456 & 12321 & 12876 \\
\hline 24 & 138 & 123 & 19044 & 15129 & 16974 \\
\hline 25 & 123 & 127 & 15129 & 16129 & 15621 \\
\hline 26 & 134 & 138 & 17956 & 19044 & 18492 \\
\hline 27 & 152 & 136 & 23104 & 18496 & 20672 \\
\hline 28 & 150 & 157 & 22500 & 24649 & 23550 \\
\hline 29 & 129 & 123 & 16641 & 15129 & 15867 \\
\hline 30 & 130 & 142 & 16900 & 20164 & 18460 \\
\hline 31 & 130 & 142 & 16900 & 20164 & 18460 \\
\hline 32 & 116 & 115 & 13456 & 13225 & 13340 \\
\hline 33 & 130 & 153 & 16900 & 23409 & 19890 \\
\hline 34 & 121 & 120 & 14641 & 14400 & 14520 \\
\hline 35 & 118 & 130 & 13924 & 16900 & 15340 \\
\hline & & & & & \\
\hline
\end{tabular}




\begin{tabular}{|c|c|c|c|c|c|}
\hline 36 & 141 & 145 & 19881 & 21025 & 20445 \\
\hline \multirow{2}{*}{$\mathrm{N}$} & $\mathbf{4 6 5 8}$ & $\mathbf{4 7 2 6}$ & & & \\
& $\mathrm{S}_{\mathrm{x}=0.604}$ & $\mathrm{~S}_{\mathrm{y}=1.114}$ & $\mathbf{6 0 6 9 0 6}$ & $\mathbf{6 2 5 8 7 2}$ & $\mathbf{6 1 4 2 6 8}$ \\
& $\mathrm{SE}_{\mathrm{x}=0.129}$ & $\mathrm{~S} E_{\mathrm{y}=0.176}$ & & & \\
\hline
\end{tabular}

a. Menentukan persamaan regresi $\mathrm{Y}$ atas $\mathrm{X}(\hat{\mathrm{Y}}=\mathbf{a}+\mathbf{b x})$ dari table diatas, dapat ditentukan persamaan atau model regresi sebagai berikut :

$\hat{\mathrm{Y}}=\mathrm{a}+\mathrm{bx}$

$\mathrm{b} \quad=\frac{\sum x y}{\sum x^{2}}$

$$
\mathrm{a} \quad=\mathrm{Y}-\mathrm{b} \bar{x}
$$

dimana :

$$
\begin{array}{lll}
\sum X=4658 & \sum X^{2}=606906 & \bar{X}=129.3889 \\
\sum Y=4726 & \sum Y^{2}=625872 & \bar{Y}=131.2778 \\
\sum X Y=614268 & \mathrm{~S}_{\mathrm{x}=0.604} & \mathrm{SE}_{\mathrm{x}}=0.129 \\
\mathrm{~S}_{\mathrm{y}=1.114} & \mathrm{SE}_{\mathrm{y}}=0.176 & \\
\sum x y=\sum X Y-\frac{\left(\sum X\right)\left(\sum Y\right)}{n} \quad=614268 & -\frac{(4658)(4726)}{36}=614268-611491,88=2776,12 \\
\sum x^{2}=\sum X^{2}-\frac{\left(\sum x\right)^{2}}{n}=606906-\frac{4658^{2}}{36}=606906-602693.44=4212.56 \\
\sum y^{2}=\sum Y^{2}-\frac{\left(\sum y\right)^{2}}{n}=625872-\frac{4726^{2}}{36}=625872-620418.77=5453.23 \\
\mathrm{~b}=\frac{\sum x y}{\sum x^{2}}=\frac{2776,12}{4212,56}=\mathbf{0 . 6 5 9} \\
\mathrm{a}=\hat{\mathrm{Y}}-\mathrm{b} \bar{x}=131.2778-(0.659)(129.3889)=131.2778-85.267=\mathbf{4 6 . 0 0 9}
\end{array}
$$

Jadi Persamaan Regresi $Y$ atas $X$ adalah $=\hat{Y}=46.009+0.659 X$

b. Uji Linearitas dan Signifikasi Regresi $Y$ atas $X$, pengujian linearitas dan signifikasi regresi $\mathrm{Y}$ atas $\mathrm{X}$ dilakukan dengan langkah-langkah berikut :

i. Menghitung jumlah kuadrat (JK) beberapa sumber varians

$$
\begin{aligned}
& \mathrm{JK}(\mathrm{T})=\sum Y^{2}=625872 \\
& \mathrm{JK}(\mathrm{a})=\frac{\left(\sum Y\right)^{2}}{n}=\frac{4726^{2}}{36}=620418,77 \\
& \mathrm{JK}(\mathrm{b} / \mathrm{a})=\mathrm{b} \sum X Y=(0.659)(2776.12)=1829.46 \\
& \mathrm{JK}(\mathrm{s})=\mathrm{JK}(\mathrm{T})-\mathrm{JK}(\mathrm{a})-\mathrm{JK}(\mathrm{a} / \mathrm{b}) \\
& \quad=625872-620418.77-1829.46=3623.77 \\
& \mathrm{JK}(\mathrm{G})=\sum_{i=1}^{i=12}\left\{\sum Y_{i}^{2}-\frac{\left(\sum Y i\right)^{2}}{n_{i}}\right\}
\end{aligned}
$$

Untuk itu data terlebih dahulu di urut menurut variable $X$ :

$\mathrm{JK}(\mathrm{G})=403+264.5+242+288+51+165+69+112.5=1595$

$\mathrm{JK}(\mathrm{TC})=\mathrm{JK}(\mathrm{s})-\mathrm{JK}(\mathrm{G})=3623.77-1595=2028.77$

ii. Menentukan derajat bebas $(\mathrm{db})$ beberapa sumber varians 


$$
\begin{aligned}
& \mathrm{db}(\mathrm{T})=\mathrm{n}=36 \\
& \mathrm{db}(\mathrm{a})=1 \\
& \mathrm{db}(\mathrm{b} / \mathrm{a})=1 \\
& \mathrm{db}(\mathrm{s})=\mathrm{n}-2=36-2=34 \\
& \mathrm{db}(\mathrm{G})=\mathrm{n}-\mathrm{k}=36-24=12(\mathrm{k}=24) \\
& \mathrm{db}(\mathrm{TC})=\mathrm{k}-2=24-2=22
\end{aligned}
$$

\section{iii. Menghitung rata-rata jumlah kuadrat (RJK)}

$$
\begin{aligned}
& \operatorname{RJK}(\mathrm{a})=\frac{J K(a)}{d b(a)}=\frac{620418.77}{1}=620418.77 \\
& \operatorname{RJK}(\mathrm{b} / \mathrm{a})=\frac{J K(b / a)}{d b(b / a)}=\frac{1829.46}{1}=1829.46 \\
& \operatorname{RJK}(\mathrm{s})=\frac{J K(s)}{d b(s)}=\frac{3623.77}{34}=106.58 \\
& \operatorname{RJK}(\mathrm{G})=\frac{J K(G)}{d b(G)}=\frac{1595}{12}=132.9 \\
& \operatorname{RJK}(\mathrm{TC})=\frac{J K(T C)}{d b(T C)}=\frac{2028.77}{22}=92.216
\end{aligned}
$$

\section{iv. Menentukan $F_{\text {hitung }}$}

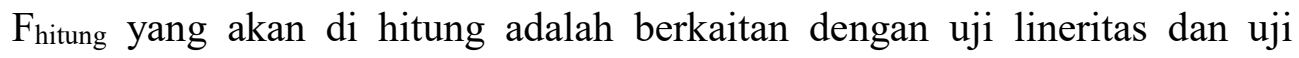
signifikansi regresi

Uji lineritas regresi $\mathrm{Y}$ atas $\mathrm{X}$

Ho : $Y=\alpha+\beta X$ (regresi linear)

Hi : $\mathrm{Y} \neq \alpha+\beta \mathrm{X}$ (regresi tidak linear)

$\mathrm{F}_{\text {hit }}(\mathrm{TC})=\frac{R J K(T C)}{R J K(G)}=\frac{92.216}{132.9}=0.693$

$F_{\text {tab }}(0.05: 22: 12)=2,23$ dan $F_{\text {tab }}(0,01: 22: 12)=3,12$

Sehingga $F_{\text {hit }}(\mathrm{TC})$ lebih kecil atau sama dengan $\mathrm{F}_{\text {tab}}$, ini berarti $\mathrm{H}_{0}$ di terima. Dengan demikian regresi $\mathrm{Y}$ atas $\mathrm{X}$ adalah linear.

- Uji Signifikasi regresi $Y$ atas $X$

$\mathrm{H}_{0}: \beta \leq 0$ (regresi tak berarti)

Hi : $\beta>0$ (regresi berarti)

$\mathrm{F}_{\text {hit }}(\mathrm{b} / \mathrm{a})=\frac{R J K(b / a)}{R J K(s)}=\frac{1829.46}{106.58}=\mathbf{1 7 . 1 6 5}$

$\mathrm{F}_{\text {tab }}:(0,051: 34)=4.13$ dan $\mathrm{F}_{\text {tab }}(0.01: 1: 34)=7.44$

Sehingga $F_{\text {hit }}(\mathrm{b} / \mathrm{a})$ lebih besar dari pada $\mathrm{F}_{\text {tab }}$. Hal ini berarti $\mathrm{H}_{0}$ ditolak pada taraf signifikasi $\alpha=0.05$ dan $\alpha=0.01$. dengan demikian regresi $\mathrm{Y}$ atas $\mathrm{X}$ adalah berarti atau signifikan. Kesimpulan dari pengujian linearitas signifikasi regresi yaitu : terdapat hubungan antara pendidikan akhlak dengan perilaku santri. 


\section{HASIL DAN PEMBAHASAN}

Setelah dilakukan perhitungan sesuai dengan rumus yang telah ditetapkan, maka didapat hasil sebagai berikut:

Rangkuman Hasil Analisis Linearitas dan Signifikasi Regeresi

\begin{tabular}{|l|l|l|l|l|l|l|}
\hline Sumber & Db & JK & RJK & $F_{\text {hit }}$ & \multicolumn{2}{|l|}{$\mathrm{F}_{\text {tab }}$} \\
\cline { 5 - 7 } & & & & & $\begin{array}{l}\alpha= \\
0.05\end{array}$ & $\begin{array}{l}\alpha \\
0.01\end{array}$ \\
\hline Total & 36 & 625872 & - & & & \\
\hline $\begin{array}{l}\text { Regresi } \\
(\mathrm{a})\end{array}$ & 1 & 620418.77 & 620418.77 & & & \\
\hline $\begin{array}{l}\text { Regressi } \\
\text { (b/a) }\end{array}$ & 1 & 1829.46 & 1829.46 & $17.165^{* *}$ & 4.13 & 7.44 \\
\hline Sisa & 34 & 3623.77 & 106.058 & & & \\
\hline $\begin{array}{l}\text { Tuna } \\
\text { cocok } \\
\text { Galat }\end{array}$ & 22 & 2028.77 & 92.216 & 0.693 & 2.23 & 3.12 \\
\hline
\end{tabular}

\section{c. Koefesien korelasi dari uji signifikasi koefisien korelasi X dan Y}

i. Koefisien korelasi antara X dan $\mathrm{Y}$

$$
\begin{aligned}
& \operatorname{rxy}=\frac{\sum X Y}{\sqrt{\left(\sum X^{2}\right)\left(\sum Y^{2}\right)}}=\frac{2776.12}{\sqrt{(4212.56)(5453.23)}}=\frac{2776.12}{\sqrt{22972058.57}} \\
& =\frac{2776.12}{4792.917}=\mathbf{0 . 5 7 9}
\end{aligned}
$$

Jadi koefisien korelasi antara $\mathrm{x}$ dan $\mathrm{Y}$ adalah 0.579

ii. Uji signifikasi koefisien korelasi $\mathrm{X}$ dan $\mathrm{Y}$

$$
\mathrm{Ho}=\mathrm{P} \leq \mathrm{O} \quad \mathrm{Hi}=>\mathrm{O}
$$

$t_{\text {hitung }}=\frac{r x y \sqrt{n-2}}{\sqrt{1-r^{2} x y}}=\frac{0.579 \sqrt{34}}{\sqrt{1-0.579^{2}}}=\frac{0.579 \times 5.831}{\sqrt{1-0.335}}=\frac{3.376}{0.815}=\mathbf{4 . 1 4 2}$

$\mathrm{t}_{\text {tab }}(0.95: 34)=1.68$ dan $\mathrm{t}_{\mathrm{tab}}(0.99: 34)=2.42$

sehingga $t_{\text {hit }}>t_{\text {tab }}$ atau $\mathrm{H}_{0}$ ditolak ini berarti bahwa korelasi antara $\mathrm{X}$ dan $\mathrm{Y}$ adalah sangat signifikan, karena kofisien korelasi adalah positif, maka dapat dikatakan bahwa koefisien antara $\mathrm{X}$ dan $\mathrm{Y}$ bersifat positif dan sangat signifikan artinya semakin baik pendidikan akhlak maka akan semakin baik pula perilaku santri.

\section{iii. Koefisien determinasi}

Koefisien determinasi adalah sebuah koefisien yang memperlihatkan besarnya variasi yang ditimbulkan oleh variabel bebas (prediktor) yang 
Qiro'ah| Jurnal Pendidikan Agama Islam

Vol. 11 No. 2 2021| https:/ejurnal.iiq.ac.id/index.php/qiroah

P-ISSN: 2085-0115 E-ISSN: 2656-3819

DOI: https://doi.org/10.33511/qiroah.v21n1.31-55

dinyatakan dengan prosentase. Koefisien determinasi didefiniskan sebagai kuadrat dari koefisien korelasi. Sehingga untuk hasil analisis di atas, koefisien determinasi atara $X$ dan $Y$ adalah kuadrat dari $r x y=0,579$ yaitu $r^{2} x y=0,335$ Koefisien mengandung makna bahwa $33.5 \%$ perilaku santri dapat dijelaskan oleh pendidikan akhlak.

Dari hasil perhitungan di atas, jika kita sajikan data tersebut dalam bentuk print out SPSS versi 17.0 maka dapat kita lihat sebagai berikut.

\section{Persamaan regresi linear}

\section{Coefficients $^{\mathrm{a}}$}

\begin{tabular}{|c|c|c|c|c|c|}
\hline \multirow[b]{2}{*}{ Model } & \multicolumn{2}{|c|}{$\begin{array}{l}\text { Unstandardized } \\
\text { Coefficients }\end{array}$} & \multirow{2}{*}{\begin{tabular}{|c|}
$\begin{array}{c}\text { Standardize } \\
\mathrm{d} \\
\text { Coefficients }\end{array}$ \\
Beta
\end{tabular}} & \multirow[b]{2}{*}{$\mathrm{t}$} & \multirow[b]{2}{*}{ Sig. } \\
\hline & B & Std. Error & & & \\
\hline $\begin{array}{l}1 \text { (Constant } \\
\text { ) }\end{array}$ & 46.009 & 0.129 & & 2.228 & .033 \\
\hline akhlak & .659 & .159 & .579 & 4.143 & .000 \\
\hline
\end{tabular}

a. Dependent Variable: prilaku santri

Dari tabel coefficients ini, konstanta dan koefisien persamaan regresi linear di peroleh dari kolom B, yaitu: $\hat{Y}=46.009+0.659 \mathrm{X}$

\section{Uji linearitas dan signifikansi persamaan regresi}

ANOVA ${ }^{b}$

\begin{tabular}{|l|c|r|c|c|c|}
\hline Model & $\begin{array}{c}\text { Sum of } \\
\text { Squares }\end{array}$ & df & $\begin{array}{c}\text { Mean } \\
\text { Square }\end{array}$ & F & Sig. \\
\hline $1 \quad$ Regressio & 1829.482 & 1 & 1829.482 & 17.165 & $.000^{\mathrm{a}}$ \\
$\mathrm{n}$ & & & & & \\
$\quad$ Residual & 3623.741 & 34 & 106.581 & & \\
$\quad$ Total & 5453.222 & 35 & & & \\
\hline
\end{tabular}

a. Predictors: (Constant), pendidikan akhlak

b. Dependent Variable: prilaku santri

Hipotesis statistik:

Ho : $\beta \leq 0$ (regresi tak linear)

$\mathrm{Hi}: \beta>0$ (regresi berarti)

Uji linearitas persamaan garis regresi diperoleh dari baris Deviation from Linearity kolom ke-5, yaitu $\mathrm{F}_{\text {hit }}(\mathrm{b} / \mathrm{a})=17.165$, dan $\mathrm{p}$-value $=0,000<0,05$. Hal ini berarti $\mathrm{H}_{0}$ di tolak. Dengan demikian regresi $\mathrm{Y}$ atas $\mathrm{X}$ adalah berarti atau signifikan. 


\section{Uji Signifikansi Koefisien Korelasi X dan Y}

Model Summary

\begin{tabular}{|c|c|c|c|c|c|c|c|c|c|}
\hline \multirow[b]{2}{*}{$\begin{array}{l}\text { Mod } \\
\text { el }\end{array}$} & \multirow[b]{2}{*}{$\mathrm{R}$} & \multirow[b]{2}{*}{$\begin{array}{c}\mathrm{R} \\
\text { Squar } \\
\mathrm{e}\end{array}$} & \multirow[b]{2}{*}{$\mid \begin{array}{c}\text { Adjust } \\
\text { ed R } \\
\text { Square }\end{array}$} & \multirow[b]{2}{*}{$\begin{array}{l}\text { Std. Error } \\
\text { of the } \\
\text { Estimate }\end{array}$} & \multicolumn{5}{|c|}{ Change Statistics } \\
\hline & & & & & $\begin{array}{c}\mathrm{R} \\
\text { Square } \\
\text { Change }\end{array}$ & $\begin{array}{c}\text { F } \\
\text { Chan } \\
\text { ge }\end{array}$ & $\begin{array}{c}\mathrm{df} \\
1\end{array}$ & $\begin{array}{l}\mathrm{df} \\
2\end{array}$ & $\begin{array}{l}\text { Sig. F } \\
\text { Change }\end{array}$ \\
\hline 1 & $\begin{array}{r}.57 \\
9^{\mathrm{a}}\end{array}$ & .335 & .316 & 10.32379 & .335 & $\begin{array}{r}17.16 \\
5\end{array}$ & 1 & 34 & .000 \\
\hline
\end{tabular}

a. Predictors: (Constant), pendidikan akhlak

Uji signifikansi koefisien korelasi dari tabel Model Summary. Terlihat bahwa pertama koefisisen korelasi $\left(\mathrm{r}_{\mathrm{xy}}\right)=0.579$ dan pada tabel Anova ${ }^{\mathrm{b}}$ di dapat $\mathrm{F}_{\text {hit }}=17.165$, dengan $\mathrm{p}$-value $=0,000<0,05$. Hal ini berarti $\mathrm{H}_{0}$ di tolak. Dengan demikian koefisien korelasi $\mathrm{X}$ dan $\mathrm{Y}$ adalah berarti atau signifikan. Sedangkan koefisien determinasi dari tabel di atas terlihat pada baris $\mathrm{R}$ square change $=0,335$, yang mengandung makna bahwa $33,5 \%$ prilaku santri dapat dijelaskan oleh pendidikan akhlak.

Dari hasil penghitungan di atas dapat di tarik kesimpulan, bahwa pendidikan akhlak di pondok pesantren Asshiddiqiyah Kedoya Jakarta sangat berpengaruh terhadap prilaku santri, ini berarti jika pendidikan akhlak lebih di tinggkatkan dan lebih baik lagi, maka prilaku santri juga akan meningkat dan akan lebih berhasil untuk memperbaiki prilaku santri.

\section{KESIMPULAN}

Dari uraian diatas, maka penulis dapat menyimpulkan beberapa hal penting yang menjadi pokok masalah dalam penelitian ini :

1. Ada tiga model pendidikan akhlak yaitu :

Pertama, Aliran atau model akhlak rasional yang didasari oleh pemikiran yang rasional yang mengacu kepada pembentukan karakter moral dan karakter kinerja. Kedua, model atau aliran pendidikan akhlak religius ini didasari oleh pemikiran yang religius, menggunakan tiga pendekatan. pertama, melalui pembiasaan, pendekatan kedua, melalui pergaulan dengan orang-orang yang berakhlak mulia. Pendekatan ketiga melalui pendidikan. Ketiga, model atau aliran pendidikan elektik, model ini berupaya memadukan pemikiran akhlak rasionalitas dengan akhlak intuisitas atau religiusitas. ada dua pendekatan yang digunakan yaitu, pertama dengan pendekatan kognitif (teoritis) melalui pendidikan dan pengajaran berbagai macam ilmu dan pengetahuan. Kedua dengan pendekatan praktis melalui pendekatan religius, keluarga, aktifitas, dan pergaulan, hukuman, nasehat, latihan, pembiasaan, keteladanan, dan lain-lain. 
Pondok pesantren Asshiddiqiyah Kedoya Jakarta dalam model pendidikan akhlaknya mengikuti aliran akhlak elektik yang memadukan antara pendekatan kognitif (teoritis) dan pendekatan praktis (langsung menerapkan atau mengaplikasikan nilai-nilai akhlak dalam kehidupan sehari-hari) dengan berbagai macam metode seperti yang telah disebutkan di atas.

2. Dari hasil perhitungan koefisien korelasi antara pendidikan akhlak $(\mathrm{X})$ dan prilaku santri (Y) di dapatkan $F$ hitung sebesar 17.165 dan $t_{\text {tab }}$ pada taraf $(0.05: 1: 34)$ adalah 4.13 dan $t_{\text {tab }}$ pada taraf $(0.01: 1: 34)$ adalah 7.44 sehingga $F_{\text {hit }}>t_{\text {tab }}$ atau $F$ hitung lebih besar dari t tabel maka $\mathrm{H}_{1}$ diterima ini berarti bahwa korelasi antara $\mathrm{X}$ dan $\mathrm{Y}$ adalah sangat signifikan, artinya semakin baik pendidikan akhlak maka akan semakin baik pula perilaku santri.

Hasil perhitungan koefisien determinasi yang menyebutkan besarnya variasi yang ditimbulkan oleh variabel bebas (prediktor). Sehingga untuk hasil analisis di atas, koefisien determinasi atara $\mathrm{X}$ dan $\mathrm{Y}$ adalah kuadrat dari rxy = 0,579 , yaitu $\mathrm{r}^{2} \mathrm{xy}=0,335$. Koefisien mengandung makna bahwa $33.5 \%$ perilaku santri dapat dijelaskan oleh pendidikan akhlak.

Dari hasil penghitungan di atas dapat di tarik kesimpulan, bahwa pendidikan akhlak di pondok pesantren Asshiddiqiyah Kedoya Jakarta sangat berpengaruh terhadap prilaku santri, ini berarti jika pendidikan akhlak lebih di tinggkatkan dan lebih baik lagi, maka prilaku santri akan juga akan meningkat dan pendidikan akhlak di pondok pesantren Asshiddiqiyah akan lebih berhasil untuk memperbaiki prilaku santri.

\section{DAFTAR PUSTAKA}

Abdullah, Abdul-Rahman Salih. "Educational theory: a Quranic Outlook." Annexe Thesis Digitisation Project 2017 Block 15, 1981.

Abrasyi, Aiyah al. "Al-Tarbiyah al-Islamiyah wa Falsifatuh.” Cet. III, Mesir: Isa al-Baby alHalaby, t. th, t.t.

Adawiyah, Robiatul. "Konsep Pendidikan Akhlak Ibnu Miskawaih." B.S. Thesis, Jakarta: FITK UIN Syarif Hidayatullah Jakarta, 2017.

Arifin, Muzayyin. Filsafat Pendidikan Islam Edisi Revisi. Bumi Aksara, 2017.

Arifin, Syamsul, Agus Purwadi, dan Khoirul Habib. Spiritualisasi Islam dan peradaban masa depan. Sipress, 1996.

Azizy, A. Qodri. Melawan Globalisasi: Reinterpretasi Ajaran Islam, Persiapan SDM dan Terciptanya Masyarakat Madani. Pustaka Pelajar, 2003.

Baraja, Umar Bin Ahmad. "Akhlak lil banin.” Juz II. Surabaya: Ahmad Nabhan, tth, 1987.

Efendi, Djohan. "Pesantren dan Kampung Peradaban (Sebuah Pengantar), dalam: Hasbi Indra, Pesantren dan Transformasi Sosial: Studi Atas Pemikiran KH Abdullah

63 | Qiro'ah| Vol. 11 No. 22021 
Syafi'ie dalam Bidang Pendidikan Islam, Hasan M." Cet 1 (t.t.).

Fauzi, Fauzi. "Model Kajian Pesantren: Studi Kritis terhadap Buku Dinamika Sistem Pendidikan Pesantren karya Mastuhu." INSANIA: Jurnal Pemikiran Alternatif Kependidikan 11, no. 3 (2006): 408-21.

Hafiz, Abdul, dan Hasni Noor. "Pendidikan Anak dalam Perspektif Alquran." Muallimuna: Jurnal Madrasah Ibtidaiyah 1, No. 2 (2016): 112-27.

Hart, Michael H. The 100: A ranking of the most influential persons in history. Citadel press, 1978.

Indra, Hasbi. Pendidikan Pesantren dan Perkembangan Sosial-Kemasyarakatan (Studi Atas Pemikiran KH Abdullah Syafi'ie). Deepublish, 2018.

Iqbal, Muhammad. "First world conference on Muslim education and its possible implications for British Muslims." Learning for Living 17, No. 3 (1978): 123-25.

Mahfudh, KHMA Sahal. Nuansa Fiqh Sosial. LKIS PELANGI AKSARA, 2003.

Maulida, Ali. "Dinamika dan Peran Pondok Pesantren dalam Pendidikan Islam Sejak Era Kolonialisme Hingga Masa Kini.” Edukasi Islami: Jurnal Pendidikan Islam 5, No. 09 (2017): 16.

Nafi, Muhammad. Pendidik dalam Konsepsi Imam Al-Ghazali. Deepublish, 2017.

Ramayulis, Haji. "Psikologi agama," 2019.

Wahid, Abdurrahman. "Pesantren sebagai Subkultur." Pesantren dan Pembaharuan, Jakarta: LP3ES, 1995. 